\title{
Tesla and the Policy behind Its Long Haul to Selling Cars in the U.S
}

\author{
Tara Fitzgerald Urich, JD, LLM \\ Oklahoma State University, Tulsa \\ 700 N. Greenwood Avenue \\ Tulsa, OK 74036, USA
}

\begin{abstract}
Tesla Motors, Inc., an American electric automobile company, uses a direct sales model to sell cars to consumers through its own showrooms. However, the traditional system for selling cars in the United States requires the use of dealer franchises. State laws, regulations and politics have made it very difficult and expensive for Tesla to operate in numerous states. This paper highlights the history of the U.S. automotive retail sales system, Tesla's rationale for their pure direct distribution model, the particulars of some state challenges and their international successes. The automotive industry is dynamic and its regulatory scheme must be flexible, not implemented to protect long standing dealer interests.
\end{abstract}

Keywords: Tesla, direct sales, automobile dealer franchise laws, direct distribution, dealership

\section{Introduction}

Tesla Motors, Inc., (Tesla)is a $21^{\text {st }}$ Century American automobile manufacturer that sells shiny all-electric vehicles through an unconventional direct distribution sales model. The relatively new car company defends the direct sales business plan as imperative for its success. It is important to briefly review the history of the conventional distribution model, the dealer franchise system, for automotive retail sales in America. Originally enacted to protect independent dealers from powerful auto manufacturers the statutes are now relied upon to insulate franchise dealers from unwanted competition. Automobile dealerships, together with dealer associations, car lobby organizations, and even some government officials have been obstructing Tesla's ability to sell cars directly to consumers. Those benefitting from the regulatory scheme are alarmed about the confrontation Tesla poses to the status quo.

\section{The Status Quo; History of the U.S. Auto Dealership Franchise System}

Americans love their cars and although the automobile has changed considerably over the years, the method for buying a new car has not. The consumer buys from a car dealership (middleman) that holds a franchise agreement with the manufacturer. This automobile dealer franchise system has remained the same in the United States for about 120 years. ${ }^{1}$ Initially, the franchise model was implemented for convenience to allow auto manufacturers to focus on manufacturing, building quality cars, and to enable dealers to focus on building community relationships in order to sell and service those cars (Gatti, 2017).The Big Three ${ }^{2}$ auto manufacturers became large, powerful and eventually overbearing, causing various state legislative repercussions during the 1930s, 1940s and 1950s (Lafontaine and Morton 2010). During this time, all 50 states passed statutes aimed at making auto manufacturers treat their dealers fairly by including protections against unwarranted franchise terminations, restrictions on additional franchise allotments in the same geographic areas, and prohibitions on manufacturers from requiring dealers to accept unwanted inventory (Crane, 2016).Furthermore, in order to prevent unfair competition from the auto manufacturers, dealers sought statutory provisions to prohibit auto manufacturers from selling cars directly to consumers; thus the status quo was codified into dealer franchise laws. ${ }^{3}$ Franchise dealerships are almost the only way to sell cars in America.

According to the National Automobile Dealers Association (NADA, 2018),17.5 million new vehicles were sold in 2016, topping \$995 billion, through the more than 16,500 franchised auto dealers in the United States.

\footnotetext{
${ }^{1}$ According to Lafontaine \& Morton (2010), General Motors Corporation set up the first franchise dealer in 1898.

${ }^{2}$ Historically, with regard to U.S. automobiles, the Big Three refer to General Motors, Ford and Chrysler, the largest automakers in the U.S. All of whom are headquartered in the Detroit, MI, area.

${ }^{3}$ In 1937, Wisconsin was the first state to adopt a dealer franchise law, and Alaska was the last in 2002 (Stolze, 2015).
} 
The state economic implications of the automobile industry are staggering - sales taxes, employment opportunities, as well as dealership infrastructure investments and property taxes. Money talks, or more specifically money influences policy, and car dealerships and dealer associations have been able to persuade state legislatures to enforce the system of dealer franchise laws in a manner effectively guaranteeing dealer profits and survival (Lafontaine and Morton, 2010) and preventing direct to consumer automobile sales. Tesla with its direct sales model has spent years and enormous amounts of money maneuvering the differing states laws to enter the U.S. automotive retail sales arena. Numerous economists, academics, and state and federal governmental agencies agree that the statutes are meant to prevent auto manufactures from selling their cars directly to consumers in competition with their contracted dealers, not to prohibit pure direct distribution (Crane, 2016). However, the strong lobbying efforts in state governments have perpetuated the protectionist franchise laws at great difficulty to Tesla and the electric car buying consumer.

\section{Tesla's Direct Sales Model}

Tesla is an electric car company and wants to sell automobiles in a way best suited for their innovative products. The company uses direct to consumer sales through owner operated showrooms, rather than traditional independent dealer franchises. As stated in Crane (2016), there is generally a strong connection between innovation in products and their distribution, requiring that new technologies create new channels to reach the market. The traditional distribution system perfected by established automobile manufacturers is not viable for Tesla as a new company that is selling a new technology in a new product (FTC, 2016).

Tesla defends its direct sales model as necessary to realize the company's broad mission, to "accelerate the world's transition to sustainable energy" (Tesla, 2018). Both Elon Musk, Chairman, Product Architect and CEO, and Todd Maron, Tesla's general council, have repeatedly shared this sentiment and back it up with a myriad of important reasons (Gatti, 2017; and FTC, 2016). The unique business model allows Tesla to hasten the introduction of mass market electric cars to the public, escape the inherent conflict of interest found at traditional dealerships trying to sell both gasoline and electric vehicles and create an overall better buying experience for customers (Zucchi, 2018).New technology and products may require different business models to find success.

It is understood that new technology must be brought to the customer and must be convenient in order to generate interest (FTC, 2016). Tesla builds smaller and more intimate showrooms to market its automobiles in high-end malls or city-center shopping areas with busy foot traffic, for consumer convenience (Fehrenbacher, 2016). There are only a few vehicles on display and employees are present to answers questions and educate interested parties or even those simply intrigued by all the hype around electric cars (Thompson, 2017). In contrast, traditional car dealerships are usually a destination comprised of large lots in out-of-the-way locations where consumers head to negotiate purchasing details (Tesla, 2018). Tesla wants its cars to be convenient so customers will become interested in the electric car company's products and its technology. It is notable that when the automobile was new and unfamiliar, manufacturers sold them directly to consumers using traveling salesmen, department stores and mail order (Clerkin, 2017). The original automobile manufacturers employed convenient ways to create interest in the new technology.

The electric car is a new technology, requiring consumers to go into Tesla showrooms to learn and maybe spend hours discussing the technical aspects of these innovative vehicles. Tesla, as the manufacturer, believes they are in the best position to educate potential buyers, and fully implement their mission statement (FTC, 2016).There is genuine doubt that traditional independent dealers would be willing to spend the time necessary to adequately educate the consumer about Tesla cars (Fehrenbacher, 2016). In fact, a secret-shopper study carried out by Consumer Reports (Evarts, 2014), investigating the technical knowledge at several automobile dealerships that stocked at least some electric cars, revealed the sales staff to be ill-equipped and unable to answer basic questions about the cars. Fifteen percent of the dealers discouraged the purchase of an electrical vehicle, and a full $40 \%$ recommended buying a conventional internal combustion automobile instead (Crane, 2016). The Sierra Club ran a study (Sierra Club, 2016), across ten states to investigate the experience of shopping for an electric vehicle at automobile dealerships with at least one electric car on their lot; finding knowledgeable salespeople and vehicle promotion severely lacking, the study concluded that automakers and dealerships have enormous room for improvement in selling electric vehicles. 
Furthermore, Tesla points out that both Fisker and Coda, other start-up new technology companies, failed in part by relying on the U.S. automobile dealership model to sell their electric vehicles (Gatti, 2017). Tesla wants control of their own fate rather than entrusting independent dealerships to sell their electric vehicles.

Traditional dealerships need to be large in size to accommodate inventory. Consumers roam expansive lots looking for the right car. Large inventories support the independent dealer business model of maintaining high volume for fast-paced sales (FTC 2016). When buying a Tesla, there is no inventory, each car is custom-ordered online directly from the Fremont, California factory (Quinland, 2013). In addition, Tesla's business model secures profit from selling new electric cars (FTC, 2016). The electric vehicle has fewer parts than gas-powered cars and requires almost no maintenance (Fehrenbacher, 2016). It is well recognized that dealers make most of their profit not from selling automobiles, but from their ongoing relationships with consumers - marketing financing products, insurance products, parts and repairs, tune-ups, and other add-on services (Henry, 2012).These different profit models make it difficult, if not impossible, for Tesla to franchise traditional dealers.

Traditional dealerships rely on the auto manufacturers to fund advertising (FTC, 2016) and they advertise, on radio, television, billboards, and in print. Tesla does not advertise, does not have an ad agency and would not permit anyone else to advertise for them and instead relies on word-of-mouth from customers, broad media coverage and brand recognition (Stolze, 2015). Dealerships rely on extensive and expensive advertising campaigns to drive interest in the vehicles they sell and would not likely depend solely on the reputation of Tesla to generate their business.

The strongest economic argument for allowing Tesla direct to consumer sales in all states is that dealers cannot make money if they try to sell Tesla electric cars at traditional dealerships. (FTC, 2016). Dealerships mark-up cars to earn a profit, but if Tesla is selling online or in a neighboring state, the consumer will purchase from the best price and the independent dealer will not be able to sell the cars (Fehrenbach, 2016).Tesla is striving to replace all fossil-fuel powered vehicles with its electric cars in harmony with its mission (FTC, 2016). Interestingly, there is a Google study (Google, 2013), predicting that $90 \%$ of cars sold in 2030 will be electric and hybrid. There is a fundamental conflict of interest between selling gas-powered internal combustion vehicles and electric cars. Traditional dealerships earn almost all of their revenues selling gas cars ${ }^{4}$, are not fully committed to the electric car and could not adequately promote their sales.

\section{Tesla-U.S. Challenges}

In 2008, Tesla introduced its Roadster ${ }^{5}$, an innovative, upscale fully electric sports car, which was followed in 2012, by the Model S, an all-electric luxury sedan (Tesla, 2018). The Model X, a premium electric sport utility vehicle that can hold up to seven passengers, became available in 2015 and in 2017, Tesla began production of the Model 3, a more affordable, higher volume consumer vehicle (Sorokanich, 2017). Since opening its first factory store in Los Angeles, California, in 2008 (Rechtin, 2008), Tesla has been defending its direct sales model and addressing dealer franchise laws in each and every state.

As of February 2018, Tesla markets their electric vehicles in factory owned "Stores" in 23 states, plus the District of Columbia, and "Galleries" in three states, Connecticut, Michigan and Texas (Tesla, 2018). Tesla stores are showrooms where consumers can see and sit in sample vehicles, take a test drive, learn more electric vehicle information, discuss costs and incentives, and even sit down at a computer to place their own order (Thompson, 2017). In contrast, Tesla galleries are a specific marketing invention where vehicles are present and employees can answer technical questions, but are not able to discuss any actual purchasing information such as pricing, financing, or leasing and may not even be able to offer vehicle test drives (Charniga, 2017). It is frustrating that Tesla cannot sell and consumers cannot buy an American made car in over half of the states because of the dealer franchise statutes.

Every state regulates the retail sales of new automobiles and requires dealers to have licenses (Lafontaine and Morton, 2010). Tesla has run into various roadblocks as it goes state by state trying to secure the necessary licenses to sell its cars.

\footnotetext{
${ }^{4}$ In 2017 , electric vehicles only represented $0.6 \%$ of national new-car sales (Welch, 2018).

${ }^{5}$ Tesla discontinued production of the Roadster in 2012, but in 2017 announced a next generation Tesla Roadster will be built in 2020 (Sorokanich, 2017).
} 
Although many states agree with Tesla's interpretation of the status quo, that the state dealership franchise laws were enacted to protect independent auto dealer's from their own manufacturer's unfair competition, other states needed convincing and still others required judicial involvement. Covering every state battle Tesla has fought or is fighting is beyond the scope of this article. However, three important states still refuse to grant dealer licenses restricting Tesla to operate only galleries in Connecticut, Michigan, and Texas. All three exemplify unique, if not ridiculous, legal barriers to entering the U.S. automotive retail sales system.

In Michigan, home of the Big Three, it is not surprising that the fight between Tesla and the statutory language to prohibit their direct sales has reached the federal court system. The largest industry and employer in the state is the automotive industry and Detroit, headquarters to the legacy US automobile manufacturers, is nicknamed "Motor City."Automobiles are big business and the dealerships, dealer associations and lobbyists heavily influence the policymakers in the state.

The Michigan Legislature (2014) amended its franchised auto dealer statute, removing the word "its" from the previous language which stated an automobile manufacturer could not "sell any new motor vehicle directly to a retail customer other than through its franchised dealers." By deleting the possessive "its" Tesla could no longer argue the statute did not apply to them as a direct distributor without a franchise dealer. The so-called "Anti-Tesla law" blocks the electric automaker from obtaining the necessary dealership license required to sell new cars (Clerkin, 2017).Based on this blatant protectionist move, Tesla has had to file a lawsuit in federal court alleging violations of its U.S. constitutional rights under due process, equal protection, and the commerce clause(Egan, 2017).

In Texas, where big oil reigns, it makes perfect sense that the state government, prompted by the automobile dealers and their associations, would try to keep electric vehicle sales at bay. It is also ironic because of the Texas-sized adoration for the free market and open competition (Lambert, 2017). In general, Texas has one of the most restrictive dealer franchise statutes (Stolze, 2015) and since 2013, Tesla has been courting the legislature to change the law to their favor (Garrett, 2016). Former Governor, Rick Perry, noted the statute provided unnecessary "antiquated protections" for the automobile industry and urged the legislature to take action (Wilonsky, 2014). Governor Greg Abbott, then stated that the Texas automotive sector works well under the current dealer franchise laws (Svitek, 2017). In May 2017, Tesla lost its third attempt to influence lawmakers to allow direct sales by automobile manufacturers, but commented it will continue to propose "fair, common-sense reforms"(Lambert, 2017).Texas is an important market for Tesla, and with galleries instead of stores, it is burdensome to sell and to buy Tesla in Texas.

Connecticut presents a peculiar situation for Tesla. Astate known for its progressive stance to address climate change, Connecticut should be a welcome market, but the largest manufacturer of electric vehicles in the U.S. is prohibited from obtaining the necessary dealer's license based on state dealer franchise law (Gatti, 2017). Tesla cannot sell electric cars in Connecticut, an affluent state that has pledged to put about 150,000 "zero emission" vehicles on the road by 2025, because of the state's car dealerships and dealer associations strong lobbying of the legislature (Sibilla, 2017). In 2018, Tesla will try for the fourth year in a row to influence state policymakers to legalize its direct sales model framing their position in economic development and environmental terms (Altimari, 2018). Tesla and Connecticut should be a "perfect fit" but car dealerships and their monopoly on the new car market prevent it (Sibilla, 2017). This conflict is another dramatic illustration of the unintended consequences of the dealer franchise laws.

\section{Tesla International}

Given the difficulties the American auto manufacturer has faced in the U.S. it is important to glance at their success in Europe and other international locations. Tesla operates direct-to-consumer stores in approximately 27 foreign countries where not one mandates the dealer franchise model statutorily required in the U.S.(Tesla, 2018). The auto manufacturer is performing well abroad and in 2017 European sales of the Model S beat sales of German gasoline luxury model sedans BMW 7 and Mercedes S for the first time, spurring the German automakers to ramp up their own electric vehicle production (Gibbs, 2018). The U.S. competition is good for business, enhancing innovation and technological advances. 


\section{Conclusions}

Regulations are an important and integral part of the automobile industry addressing innumerable issues including safety, lighting, durability, theft protection, environmental impacts and even new and used car sales methodologies. The purpose of the dealer franchise laws, originally passed mid-twentieth century, was not to fortify the independent dealership as the only method for U.S. automotive retail sales forever, but to serve a useful purpose for the times. Times have changed. Based on the dynamic nature of the automobile industry its regulations must be dynamic too. The U.S. automotive retail sales regulatory system must be flexible to accommodate the ever-changing industry. Governmental policy should not be determined by special interest groups, franchise dealerships, hoping to perpetuate their success. New technologies and products need access and should be encouraged to join the competition. Tesla, with its pure direct distribution model, has fought, and is still fighting, state by state for the ability to sell their innovative environmentally friendly electric cars, confronting the status quo, an archaic law that should not even apply to them.

\section{References}

Altimari, Daniela. 2018. "After Four Years of Trying, Tesla Hopes to Win Approval to Sell Cars in Connecticut." Hartford Courant, February 10. http://www.courant.com/politics/hc-pol-tesla-legislation-20180209story.html.

Charniga, Jackie. 2017. "Tesla to open larger gallery in Michigan.” Automotive News, September 8.

Clerkin, Bridget. 2017. "Appetite for Disruption: Tesla's Push to Shatter the Car Buying Landscape." DMV.ORG, June 26. https://www.dmv.org/articles/appetite-for-disruption-teslas-push-to-shatter-the-carbuying-landscape/.

Crane, Daniel A. 2016. "Tesla, Dealer Franchise Laws, and the Politics of Crony Capitalism." Iowa Law Review 101, no. 2:573-607.

Egan, Paul. 2017. "Federal Judge in Tesla case: Lawmakers must turn over records to electric automaker." Detroit Free Press, August 21.

Evarts, Eric. 2014. "Dealers Not Always Plugged in About Electric Cars, Consumer Reports' Study Reveals." Consumer Reports, April 22. http://www.consumerreports.org/cro/news/2014/04/dealers-not-alwaysplugged-in-about-electric-cars-secret-shopper-study-reveals/index/htm.

Federal Trade Commission. 2016. "Auto Distribution: Current Issues \& Future Trends." https://www.ftc.gov/system/files/documents/public_events/895193/auto_distribution_transcript.pdf. Pages 88-94 (last viewed February 11, 2018).

Fehrenbacher, Katie. 2016. "7 Reasons Why Tesla Insists on Selling its Own Cars." Fortune, January 19. http://fortune.com/2016/01/19/why-tesla-sells-directly/.

Garrett, Robert T. 2016. "Texas auto dealers receive Tesla-sized dent from state GOP.” Dallas News, May 20. https://www.dallasnews.com/news/politics/2016/05/20/texas-auto-dealers-receive-tesla-sized-dent-fromstate-gop.

Gatti, Daniel. 2017. "Why You Can’t Buy a Tesla in Connecticut (and 5 Other States)."Blog,Union of Concerned Scientists, February 22. https://blog.ucsusa.org/daniel-gatti/why-you-cant-buy-a-tesla-in-connecticut-and5-other-states.

Gibbs, Nick. 2018. "Tesla Model S outsells German luxury flagships in Europe." Automotive News Europe, February 20. http://europe.autonews.com/article/21080220/ANE.

Henry, Jim. 2012. "The Surprising Way Car Dealers Make the Most Money off You." Forbes: Autos, February 29. http://www.forbes.com/sites/jimhenry/2012/02/29/the-surprising-way-car-dealers-make-the-mostmoney-off-you.

Lafontaine, Francine, and Fiona Scott Morton. 2010."Markets: State Franchise Laws, Dealer Terminations, and the Auto Crisis."Journal of Economic Perspectives24:233-250.

Lambert, Fred. 2017. "Tesla's direct sale effort in Texas fall again, complicating things for Model 3 buyers." Electrek, May 31. https://electrek.co/2017/05/31/tesla-direct-sale-texas-model-3/.

Michigan Legislature. 2014. House Bill 5606, October 21.http://www.legislature.mi.gov/documents/20132014/publicact/htm/2014-PA-0354.htm.

National Automobile Dealers Association (NADA), 2018. NADA Data. https://www.nada.org/nadadata/. 
Quinland, Roger M. 2013. "Has the Traditional Automobile Franchise system Run Out of Gas?" American Bar Association Franchise Law Journal 16, no. 3.

Rechtin, Mark. 2008. "Tesla Opens First Dealership in Los Angeles." AutoWeek, May 1. http://autoweek.com/article/car-news/tesla-opens-first-dealership-los-angeles.

Sibilla, Nick. 2017. "Connecticut Should be Tesla Country.” The New York Times, July 7. https://www.nytimes.com/2017/07/07/opinion/connecticut-tesla-dealership-laws.html.

Sierra Club. 2016. "First-Ever Multi-State Study on Electric Vehicle Shopping Experience." https://content.sierraclub.org/press-releases/2016/08/first-ever-multi-state-study-electric-vehicleshopping-experience.

Sorokanich, Bob. 2017. "This is the last Tesla article you need to read today, we swear." Road and Track,November 17.

Stolze, Eric D. 2015. “A Billion Dollar Franchise Fee? Tesla Motors' Battle for Direct Sales: State Dealer Franchise Law and Politics." American Bar Association Franchise Law Journal 34, no. 3:293-309.

Svitek, Patrick. 2017. "Tesla tries a new, ambitious approach at Texas Capitol." The Texas Tribune, March 10. https://www.texastribune.org.2017/03/10/tesla-tries-new-approach-texas-capitol/.Tesla. 2018. https://www.tesla.com/.

Thompson, Meg. 2017. "Tesla Stores: What Are They and How Are They Different Than Dealerships?" The News Wheel, September 26.

Wilonsky, Robert. 2014. "Gov. Rick Perry: It's Time for State to Revisit 'Antiquated' rules that Prohibit Tesla Sales in Texas." Dallas Morning News, March 24.

Zucchi, Kristina. 2018. "What Makes Tesla's Business Model Different?" Investopia, January 25. https://www.investopia.com/articles-trading/072115/what-makes-teslas-business-model-different.asp. 